2013-01-01

The Pornographics of Japanese Negrophilia

\author{
Aoki, Darren
}

http://hdl.handle.net/10026.1/12886

Japan Forum: the international journal of Japanese studies

Taylor and Francis

All content in PEARL is protected by copyright law. Author manuscripts are made available in accordance with publisher policies. Please cite only the published version using the details provided on the item record or document. In the absence of an open licence (e.g. Creative Commons), permissions for further reuse of content should be sought from the publisher or author. 


\title{
The pornographics of Japanese negrophilia
}

\author{
Jonathan D. Mackintosh
}

To cite this article: Jonathan D. Mackintosh (2013) The pornographics of Japanese negrophilia, Japan Forum, 25:1, 1-23, DOI: 10.1080/09555803.2012.737352

To link to this article: https://doi.org/10.1080/09555803.2012.737352

Published online: 05 Dec 2012.

Submit your article to this journal

Џll Article views: 365 
IB Rouldede

Taylor \& Francis Group

\title{
The pornographics of Japanese negrophilia
}

\author{
JONATHAN D. MACKINTOSH
}

\begin{abstract}
In 1974, a bizarre story, 'Jigoku ni ochita wakamonotachi' ('Young Men Fallen into Hell'), appeared in the Japanese homo magazine Adon. It described in pornographic detail the sado-masochistic torture of Japanese men captured and forced to perform in a black circus troupe in American-occupied Japan. 'Jigoku' was unremarkable except that, in its stylised 'pornographics', it uniquely - for the homo imagination - configured sexual desire as a Japanese-black inter-racial intercourse. This article explores this imagination through a close reading of 'Jigoku'. It traces a post-war 'genealogy' of blackness (Russell 2006), which finds affinity of meaning and value cutting across sub-cultural homo sexual fantasy, through mainstream-to-canon literature and arthouse cinema, across the post-war era. Many of the stereotypes are familiar, but there is a twist. The 'libidinously liminal' scenario that sees in 'Jigoku' a racial play of Japanese colouring-up and a minstrelsy of sorts upsets cultural narratives of Japan's post-war period. So too does the extremity of the sado-masochistic fantasy present in 'Jigoku'. In its audacity, the world is expunged of white men. A new moral history is suggested in which the trauma of defeat and occupation can be re-membered and men (re-)masculinised in the pleasurable tortures they suffer at the hands of their black masters.
\end{abstract}

Keywords: postwar Japan, black representation, masculinity, pornography, sado-masochism

An odd piece of pornographic fiction appeared in the August 1974 edition of Adon, one of the first magazines in Japan to cater expressly and exclusively to homo, as male homosexuals were then known. Titled 'Jigoku ni ochita wakamonotachi' ('Young Men Fallen into Hell'; 'Jigoku' hereafter), its story of young Japanese men enslaved and forced to perform in a black circus troupe in Americanoccupied Japan was fanciful. Its descriptions of ever-more-implausible forms of male genital cruelty, or in today's sado-masochistic argot kyüsho kögeki ('cockand-ball torture'), was somewhat specialised, though to be sure male-male 
sado-masochism featured as a main theme in the various short stories and serialised novels that were published to make up the homo magazine's pornographic corpus. ${ }^{1}$ What makes this story distinctive is its imagination of male-male inter-racial intercourse. Indeed, in my sampling of magazines featuring male-male sexuality during the period 1952 to 1975 , there are only a handful of depictions of such a scenario, some of which I have treated elsewhere (see Mackintosh 2010).

One might ask why such dedicated and full treatment of this story is justified, particularly when its writing exemplifies the trademarks of mass-produced pornographic literature: formulaic plotlines; derivative settings; the commodification of bodies, fragmented into their objectified components, and especially their naughty bits; graphic depiction of sex acts in excessive detail; and thin characterisations. Indeed, the narration of 'Jigoku' is so concentrated on, and matter-of-fact in, its description of acts that the motivations and desires of the characters - Japanese and black - are hardly addressed. Finally, all of this is topped off with not just one orgasmic money shot, but many: 'we used our hips and ejaculated' (Nagano 1974 b, p. 55). As this literal translation indicates, so wooden is the writing that it seems hardly conducive to even the standard model of consumption used to describe pornography: the 'taking in of the consumed object in a mindless or insensate state, the engorgement of pleasure' (Wicke 1993, p. 68); what Linda Williams might identify as 'frenzy' (Mui 1991). Never mind any pretence to exploring the metaphysical aspects of sexuality in meditations on eroticism, 'Jigoku' emerges, it seems, as yet one more crudely made product in 'a ruthless, totalising system of mass cultural entrapment, freezing its consumers in postures of reification rather than the sportive sexual positions it ostensibly favours' (Wicke 1993, p. 69). Yes, mistress(!). Except that sex/race as represented in 'Jigoku' is not massproduced. Notwithstanding the fact that there is, so far as I have found, no other imagination of a black-Japanese male-male coupling in homo fiction, this text in fact is rich in the longer-term historical and cultural context on which it draws; and in a rare moment, it enables us to explore an otherwise little-appreciated intersection between history and memory.

J.G. Russell (1991, p. 5, 2006) extends a valuable historicising model that describes a 'presence of black people', through which 'various forms of black culture - either directly or indirectly by proxy - and their representation in Japan' forms a long-term 'genealogy'. Here, the distinction between actual and virtual contact is of less relevance than the powerful affects that this genealogy produces in the invocation, reproduction and re-inscription of its constituent racial iconographies and racist stereotypes. In 'Jigoku', in the words of Bhabha, these iconographies and stereotypes give:

access to an 'identity' which is predicated as much on mastery and pleasure as it is on anxiety and defence, for it is a form of multiple and contradictory belief in its recognition of difference and disavowal of it.

(Bhaba 2004, p. 107) 
In other words, culture and history are revealed - re-membered - through the body as ecstasy and trauma, contradictions of desire and fear; and as crude as its racial stereotypes are, the genealogy of the black presence from which it draws visual form and affective meaning can also explore a genealogy of Japanese cultural expression.

In fact, the genealogy of the black presence as a form of cultural memory is technologically aided, generated and disseminated in the twentieth-century mediascape of publishing, photography, recording, radio and film. It is, as Landsberg (1995, pp. 175-176) identifies it, 'prosthetic': that is, 'memories which do not come from a person's lived experience in any sense', 'implanted memories' that '[unsettle] the boundaries between [the] real and simulated'. 'Non-essential' but not fake, 'unstable' yet steadying in the knowledge that its constituent stereotypes confirm, and 'ungrounded' even as it is historical, it is the ambiguous spaces of race-intersecting-with-sex which the genealogy of the black presence inter-textually opens, and to powerful effect. Indeed, as Russell observes, 'its reception, imitation, and appropriation':

[have] become yet another means by which Japanese are constructed as Other and of authenticating old stereotypes about fapanese alterity, while simultaneously perpetuating notions of blacks as the Ultimate Other, constructing an unbreachable rift between Blacks and Asians.

(Russell 2006)

Does 'Jigoku' offer a reflective cultural critique, a political manifesto on race that radical sex - an anti-phallic sado-masochism - only serves to amplify? No. But, as this article will explore, it does alert us to aspects of this prosthetic imagination of blackness that traces a genealogy of meaning across Japanese modernity. This imagination comes into sharper focus when we consider that the pornographic translation of racial understandings that appears in 'Jigoku' is also present in other cultural products: for instance, literature, film and cartoons. This article will reference these to catalogue inter-textually the desire for an imagined 'blackness', a post-war Japanese negrophilia.

We do well to heed Mui's warning in her review of Linda Williams' analysis of porn film:

$[\mathrm{O}]$ ne wonders if such meticulous, sophisticated analysis has not diverted too much this low-budget production, especially when one considers that the symbolisms identified are admittedly neither intended by the filmmaker [... ] nor perceived by the viewer who is there primarily for a quick sexual outlet.

(Mui 1991, p. 119)

Too much cultural theory may similarly kill off the pornographic intent of 'Jigoku', which, at six pages, is surely shorter than this article. That said, the story's porn can too easily be stroked off as a masturbatory aid, whose only useful comment is a common-sense one on male physiological-psychological motivations: 'Obviously 
the cock is the organ of the male body most effectively wired for pleasurable sensation' (underscore in original) explains the entry on cock-and-ball torture in an online pornographic encyclopaedia of extreme sex:

But arguably more important is the psychological angle: for many men, cocks are the centre of sexuality and a symbol of sexual potency and when someone helplessly undergoes abuse of his most precious appendage the psychological charge is immense. A site normally associated with indulgent pleasure is being transformed into a vulnerable target for punishment and pain.

(London Fetish Scene 2010)

No comeback is here required. But, the 'psychological charge' may be usefully explored by a turn to history and culture; indeed, helplessness, preciousness, pleasure, punishment and pain are social affects, a sexual appeal to hierarchy and supplication to power, all of which reconfigure the sexual as racial: concupiscence is profoundly communal, relying on cultural boundaries of belonging and alterity.

If by 'poetics' we mean an aesthetic stylisation that is intuited in an imaginative reading of culture (Highmore 2002, pp. 145, 151), and by 'erotics' we identify a 'stylisation' in the 'purposeful art of love' (Foucault 1990, pp. 35, 229), then in a 'pornographics' we find the simulation of sex purposefully imagined for the stimulation of carnal desire. Insofar as a pornographics can be understood as a stylisation literally of explicitness and excess - the harder, the wetter, the bigger, the louder, the closer-up, and so on - this pornographics is purposefully aesthetic. While its exaggerated moans and plentiful money shots may betray a culture of formulaic reproduction, its play with cultural meaning - images, motifs, idioms and morals - betrays a certain imaginative creativity. In 'Jigoku', quality and worth are not located in glimpses of erotic contemplation; there is none to be found. But, in its pornographics of the black presence, we might nevertheless gain valuable access to a prosthetic memory which pricks Japanese understandings of sex/race and historical value.

\section{Pornographic excess and the eugenic imagination}

Nagano Hikari's 'Jigoku' reports, in the form of recollections, his own life in the world of the circus. Told in two parts, it escorts the reader through the protagonist's induction into a black-American circus troupe in the wake of Japan's Second-World-War defeat and subsequent American occupation (in the August 1974 instalment), and his early career performances as a trapeze and high-wire artist (in the September 1974 instalment). This tale of 'lurid vividness', as the editor promotes it (Nagano 1974a, p. 50), describes a series of sado-masochistic scenarios that, in the wider geo-sexual context from which it draws, render an unexpected imagination of Japan's post-war post-colonial initiation into the Pax Americana. 
The provenance of this piece is unclear. Sent in by a reader who, apparently, was so inspired by the inauguration of Adon in 1974 as to write this piece, the ascription of a pen name nevertheless maintains the author's anonymity, a convention of Japanese post-war erotic writing. The extraordinary assertion that the episodes are, in fact, non-fiction caused some discussion: to readers' suspicions over the introductory instalment - 'Isn't this fabricated?' they queried the editor, unconvinced himself, replied by describing the next chapter as a 'true story that is like a modern myth' (Nagano 1974b, p. 42: emphasis in original); meanwhile the author protested the truth of his tales by providing a photo. In it, a nude young man foregrounds a scene in which eight or nine other naked Japanese men help fully clothed fishermen prepare their boat for an outing. The photo ostensibly gives witness to an encounter with the residents of a remote fishing village which the circus was travelling through, an encounter that is described in the second instalment (Nagano 1974b, pp. 43-44). The exaggerated artistic license that surely colours, for instance, the scene of a Bacchanalian orgy following a day out at sea - in which fishermen and performers share sake, cock-sucking and sodomy, all in imaginatively contorted body positions is characteristic of the episodes that the reader encounters. The verisimilitude of 'Jigoku' is certainly suspect. However, the imagination of blackness that it explores, if fleetingly, is significant in moral-historical ways, especially given the extra-textual context which saw some Japanese in the homo magazines actively attempt to reconstitute their own manly identities through race. This much can be seen in the first instalment, where black men feature most, and so it is to this instalment that the following discussion gives its primary focus.

Set somewhere in Japan's southern islands in the early part of the American occupation of Japan (1945-1952), the August instalment of 'Jigoku' recounts a bizarre tale of young Japanese conscripted soldiers captured for training by an all-black, all-male, all-nude circus troupe. Upon learning that the protagonist is skilled in the circus arts, his captors enlist him to train for and perform in the aptly-named Black Ring circus.

Most of the first instalment is given to detailing the daily training regimen, which includes all manner of sexual torture. At one level of analysis, the 'inside view of a circus troupe' that the story's byline announces can be understood as a shallow pretext to indulge in pornographic excess. That being said, the circus setting is not wholly irrelevant: it animates the fantasy so that, common to much sado-masochistic erotic writing, discipline - in this case, training in the circus arts - does not merely make an otherwise unthinkable act logical. Rather, in the brutality it describes, an other-worldly - libidinously liminal ${ }^{2}-$ atmosphere $^{2}$ permeates the text to structure an approach to pain whose pleasurable imagination becomes, of course, a moral matter. For example, because swaying testicles are a 'great nuisance' to walking the tightrope, those of the Japanese youths are bound in dog leather, with the result that their 'dangling balls disappear' (Nagano 1974a, p. 53). Described in three short lines, the utter normality of the act renders genital 
modification a moral baseline against which extremity can be measured anew. A hinted-at nullification serves to underscore acts much more unimaginable and hence stimulating, as in the euphemistically titled 'prawn punishment'. Here, a man who fails to restrain himself from ejaculating when forcefully masturbated by his trainer is 'made to sit cross-legged with a thin chain fastened around his ankles':

This chain is wound round his neck, and then passed back down through his bound ankles, and raised from the mat to be suspended at about one-and-ahalf metres. The young man moans quietly. But then, electric wires are inserted into his anus and urethra. Both wires are connected to a power supply, and he shrieks and passes out. A bucketful of water is thrown on him, and when he comes to, the electric punishment begins again. In the process, as a result of the ebi seme, his entire body turns bright red, and next blue.

(Nagano 1974a, p. 52).

Extending over almost one third of a page, the gratuitousness and exactitude characterising this passage's detail are not atypical. They are also not without purpose and effect. In the excessive embellishment of 'memories' whose core kernel may - or not - relate truthful experiences, claims of the story's ostensible veracity were nonetheless deployed in an editorial pimping strategy to entice readers, as we saw in the discussion between readers and the editor.

Moreover, this detail is discursive in two related ways. As an illustration, consider the first encounter of the Japanese youths with their black captors. Upon being taken prisoner, the young men are sent to a black military nursing training unit. Restrained spreadeagled on the examining table following a forceful full-body scrub down with a coarse-haired brush, their genitals and anus are measured externally and internally with various forms of probing, and, finally the youths put in the role of the experimental guinea pig - they are subjected to all manner of injections and medical procedures (Nagano 1974a, pp. 50-51). Of the 200 men taken captive, only around ten to fourteen of the fittest fifteen-totwenty-two year-olds - all perfectly formed at ' $160 \mathrm{~cm}$ in height or thereabouts', with penises that are uniformly around thirteen centimetres in length (Nagano 1974a, p. 51) - are identified as an elite, and thereafter, they enter into three years of circus training, the 'Hell' of the story's title.

These sequences draw from and generate the stock-in-trade pornographic subgenre $^{3}$ of medical sado-masochism (Tempest 2006), what in the Japanese internet porn market might be identified as iryō fetchi ('medical fetish'). But, the play with popularised understandings of medical procedure doesn't operate in isolation. Animating the scenarios of medicalised humiliation and pain in 'Jigoku' is a powerful cultural memory that recalls elements of a mid-twentieth-century technologically driven eugenic imagination (Mackintosh 2010, pp. 104-109), one that pre-occupied the occupier and occupied alike. As Dower (1999, pp. 79-80) critically observes of the American occupation authorities: 'Japanese militarism and 
ultranationalism were construed as reflecting the essence of a feudalistic, Oriental culture that was cancerous in and of itself.' The eradication of these 'involved denaturing an Oriental adversary and turning it into at least an approximation of an acceptable, healthy westernized nation'. The concerns over bodily fitness were especially pertinent to the Japanese, whose vaunted if invented traditionalistic bushidō (samurai warrior code) aesthetic was wholly discredited. No longer could it be argued that a 'superior spiritual energy [... ] distinguished them from their sometimes materially stronger adversaries' (Low 2003, p. 86. C.f. Dower 1986, pp. 21-67). Instead, Japanese scientists pressed for a regimented overhaul of the diet to improve their countrymen's physical structure (Koshiro 1999, p. 68). In the imagination of defeat and occupation of 'Jigoku', medical torture is frightfully calculated and scientifically rational in its bodily discipline; American modernity is portrayed as frenzied in the invasiveness and democracy of its eugenic techniques; all the Japanese are treated to the same examination and experimentation in this bio-political imperialism (Kelly 2010). ${ }^{4}$

That is not all, since the scenario of Japanese bodily violation is then cast in racial terms. The young protagonist and his compatriots are not subjugated simply as a result of their military defeat; their humiliation comes as a result of being relegated to the lowest rank of the racial pecking order. While conventional representation of the occupation unsurprisingly ponders power disparities in the relationship between the victor and the vanquished, the black-to-Japanese scenario of 'Jigoku' disrupts what would otherwise be a position of parity that directly relates white America and its erstwhile Oriental enemy. ${ }^{5}$ Here, the Japanese is plucked out of an occupation that was his very own to be planted into what was, in policy and practice, an American apartheid that racially segregated blacks - and now Japanese - from whites. ${ }^{6}$

\section{A cultural genealogy of the black presence}

To identify the generic quality of 'Jigoku' is not to belie its discursive power. On the contrary, its libidinously liminal fantasy, as articulated in the medical scenario, manipulates the cultural memory of wartime defeat and the occupation, and the possibility of an alternative knowledge of sexuality is presented. The excess of the story alerts us crucially to how the erotic may be configured as the historically exotic. Black men appear as more than an incidental curiosity in the ambiguous space through which they are represented. Rather, blackness reconfigures the occupation narrative; it denaturalises it to encode cultural memory anew (Hall 1980).

Central to this process is the primacy of focus given to the penis, and in turn, its signifying power. Marked by the letter ' $\mathrm{M}$ ', which stands for mara ('cock'), the penis in 'Jigoku' stands out conspicuously from the Japanese characters surrounding it, a prominent visual-textual protrusion as if to beckon the reader to its hardest-core bits. There are also the tortures that the Japanese penises suffer 
in the hands of the black Others: orgasm-denial exacerbated by prolonged enema; penile canings with a bamboo rod; and, suggesting that the story's tongue was sometimes poking its own cheeks, there was the incongruous dobin watashi, in which the failure to suspend a ceramic teapot from one's erection was greeted with severe punishment. When it came to the representation of the blacks, however, no such irony is evident, despite their stereotyping. Describing one of the black trainers called King, the protagonist observes a 'jet-black solid-bodied negro man short in stature, but who possesses a big thing' (Nagano 1974a, p. 51). Note here that, in contrast to the explicit prominence of the Japanese penis, the black penis is a 'thing' ('mono'); hugely fascinating yet unfathomable.

At this point, it is useful to draw the black penis out of the narrow context of 'Jigoku'. By invoking a longer-term historical perspective, we find that the signifying function of the black penis calls not simply on a common stereotype. Rather it alerts us to a wider genealogy of meaning and, hence, moral value. Fast forward a decade or so and Yamada Amy would cause scandal with her description of a black man's penis in Bedtime Eyes. Featuring Kim, a Japanese prostitute, who shacks up with Spoon, a black American military deserter, the novella's imagination is cutting in its comparison of Spoon to her compatriots:

His dick $[d i k k u]$ wasn't [ ... ] the pathetic infantile thing of Japanese men, the kind that doesn't do a thing for you until it's inside you. [...] With Spoon [... I I was totally in awe of his dick. It was gorgeous, like a big chocolate bar. (Yamada 2006, pp. 56, 1987, pp. 14-15)

Yet, the direct phallic threat that Yamada's protagonist represents to Japanese masculinity both in her novella and in the media discourses it enflamed - 'The male-dominated Japanese media [...] salaciously excoriate[ed] the women as sexually insatiable sluts in thrall to the black phallus' (Kelsky 2001, p. 134) is only part of what defines black menace in 'Jigoku'. Even in the sparseness of detail that attends the portrayal of King, it is a fearful wonderment that is detectable at the size, solidness and beast-like blackness of the bodily frame it metonymically describes. If anything, the protagonist of 'Jigoku' is akin to the narrator's 'erotic attraction for the foreign soldier himself' (Molasky 1999, p. 76) that characterises Ōe Kenzaburō's 1958 Shiiku (The Catch), in which a downed American airforce pilot, held prisoner by villagers, is gazed upon by the village children: 'His naked, wet body [...] shone like the body of a black horse. [...] Suddenly, we noticed that the Negro had a splendid, a heroic, and unbelievably beautiful phallus [sekkusu]' (pp. 47-48, 124-125).

The relationship of 'Jigoku' to Ōe's earlier and renowned Akutagawa Prizewinning story may be derivative. Indeed, Shiiku's main scenario and the hierarchy of power that structures the relationships between its key characters is notably similar, if in mirror reflection: to Ōe's captive black soldier and his Japanese boy captors in the libidinously liminal setting of a village that 'exists nowhere in actual Japan' at war's end (Molasky 1999, p. 76), 'Jigoku' sees a Japanese youth enslaved 
by black men in the similarly libidinously liminal setting of a circus at war's end travelling the peripheral islands of a country found at the periphery of America's newly expanded empire; to Ōe's meditation on shifting positions which sees the main Japanese boy '[vacillate] between his responsibility to act as warden of the animal-like prisoner and his desire to submit to the black man's erotic power' (Molasky 1999, p. 81), 'Jigoku' simplifies the black-Japanese relationship into a sexual hierarchy of power.

In juxtaposing the pornographic take of 'Jigoku' with the literary representation of blackness in Ōe - and, anachronistically, Yamada too - a post-war genealogy of recurring images is summoned. It includes bestial danger: in Ōe (1981, p. 50), for example, 'The Negro soldier had changed back into the black wild beast'; in Yamada (2006, p. 47), '[Spoon] slowly opened his eyes to look down at his prey. $\mathrm{He}$ ground his teeth together'; in 'Jigoku', '[Black trainers] were evil-looking, hugebodied powerful men'. It includes animalistic primitiveness: in all three stories, black men - whether as a captured soldier in Ōe's fable, an absconding private in Yamada's tale, or a conquering occupation master in 'Jigoku' - are, as Molasky (1999, p.78) observes of Shiiku, '[denied] the power of speech'. Of course, this silencing, through which we learn nothing of the black characters' thoughts and desires, only serves to exoticise the black bestial presence, especially in 'Jigoku'. And, finally, there is the black man's penis, which sets up sex/race as a signifier of alterity, and 'an oppositional marker of cultural, social and physical otherness remains vigorously intact' (Russell 2006). Note in these three differing imaginations the mechanisms of racial othering. Here, the simplistic dichotomy of black nature versus the taming technological force of white civilisation is complicated by an added layer of inter-racial intercourse. The use of blackness to signify the American military threat simultaneously prises open cracks within the disciplining force of American colonial power which the Japanese characters in Ōe subvert, in Yamada exploit and in 'Jigoku' find an unexpected desire.

It is germane at this point to heed Molasky's (1999, p. 71) warning to recognise the salient differences amongst various works in an effort to avoid an analysis that 'reduces all representations of blacks to a single mold'. These images are not simply appeals made to the cultural spectre of blackness necromanced through some talismanic citation of a historical racist stereotype; rather, bestial danger, animalistic primitiveness and sex/race are deployed to explore in greater or lesser reflection historically specific subjectivities as set in relief against the Japanese Other. That being recognised, all three stories share in their consumption, and in turn, construction of a long-term 'black presence' within a transnational massmarket mediascape of racist discourses circulating across modernity, so that race 'is played with and performed in an almost identical manner globally [... ] [and] is inscribed, effaced and re-inscribed across national borders' (Russell 2006). Compare, for instance, images of Micronesian natives in Shimada Keizō's 1930s animated film series Daring Dankichi (cited in Baskett 2009, p. 48, Dvorak 2008, p. 73) with the portrayal of natives in the Warner Brothers film The Isle of Pingo 
Pongo in 1938. While both feature gangly, long-limbed naked figures, wrapped only around their waists to protect their modesty, it is the pointy shape of the head, with round ears jutting out from the sides, and white eyes and mouth regions set in high relief the blackness of their simian-like faces that is so strikingly similar (Baskett 2009, pp. 47-49, Dvorak 2008, p. 73, Avery 1938). Arguably, Daring Dankichi imagined blackness according to Japan's trans-Pacific imperial imaginary that included Micronesia, whereas the natives of Pingo Pongo are seen to transmute into jazz-dancing figures to recall America's transatlantic cultural transactions.

\section{Slavery and minstrelsy: cultural memories by proxy}

By the 1970s, when 'Jigoku' was published, over a century had passed since the abolition of slavery in the United States. Yet, this history - whose antecedents and influences include, for instance, the importation of images of African slaves into sixteenth-century Japan, or much later, modern black minstrel performance constitutes a cultural memory by proxy, ${ }^{7}$ existing tenaciously in the recesses of the imagination, but when prodded powerfully shapes how blackness might be understood. The theme of black captivity is one aspect of this and configures the central relationships in Ōe and Yamada: an American pilot imprisoned in a boar trap; the military deserter Spoon ensconced in Kim's apartment, unable to leave for fear of being arrested by US military authorities, giving Kim, 'actually the satisfaction of owning him' (Yamada 2006, p. 38).

In 'Jigoku', the spectre of slavery is not simply a metaphor for captivity; it is directly invoked, but with master and slave positions provocatively reversed. There is the cluster of signifying accoutrements: number cards worn round the naked Japanese youths' necks; ball-and-chains to restrain and fasten men to each other; and their black masters' whips ubiquitously snapping (Nagano 1974a, pp. 50-51). Recalling plantation owners' dance competitions (Knowles 2002, p. 50), 'Jigoku' depicts individual Japanese slaves as the 'betting objects' of groups of black onlookers, forced to perform various circus feats. The sexual objectification of the Japanese slave was, moreover, institutionalised, his body disciplined and dehumanised into a kind of free-access sex machine: 'tied between two palm trees, our arms and legs spread wide, we were forced to partner with the black soldiers who passed by' (Nagano 1974a, p. 51). And, when the Japanese slave failed to perform, he was subjected to a 'lynching [rinchi]' (Nagano 1974b, p. 43) ${ }^{8}$. In 'Jigoku', it is the cultural memory by proxy of slavery, detailed unambiguously, that generates black menace, and which amplifies the sense of threat that attends the signifying cluster of black penis/body/race. This negro-slave parable that reimagines Japan's defeat and occupation as a new American slavery colours the sado-masochistic tortures. Abuse isn't simply a physiological and sexual sensation; it is also a cultural violation of Japanese male identity and integrity. 
Or is it? In the concluding scene of the first instalment of 'Jigoku', the plot is brought to an ambiguous resolution which sees the black menace appropriated, if never fully tamed, in a bizarre play at racial play. Completing their first three months of training in the circus arts, the Japanese slaves are forced to give a graduation recital of sorts. The 'Gold and Silver Gilt Show' is a variety performance including penile acrobatics featuring gigantic $M$, a very special trapeze routine, amongst other acts, all exclusively for the delectation of black male troops. From the perspective of genre pornography, the Gold and Silver Gilt Show is a kind of finale. To be sure, there is a money shot involving ejaculation, but in comparison to the lush choreography of each and every cock-and-ball torture suffered, it is anti-climactic, a minor triviality. The real focus is the $k \bar{o} k e i$, the final glittering scene of spectacle in which Japanese, on all fours, offer their asses to 'wild samba rhythms', all in a blizzard of light thrown off by the mirror ball; and as if to evoke the narrative structure of an affiliated genre, the musical, the show itself - its dance numbers mixing blacks and Japanese, costuming, lighting and frenzy - is the climaxing star. ${ }^{9}$

Not that 'Jigoku' is a critical attempt to play with genre formulae. But the training in the circus arts and its finale performance, when considered alongside the fact that this is a travelling circus troupe which goes from base to base to play forand with - black troops, does not merely create a pretext for sex. Rather, it draws through a sub-textual allusion to minstrelsy, one that comes to its full fruition in the reference made to blacking-up, or more accurately colouring-up, that is re-iterated over and again in the ultimate scene. Here, the two most outstanding men, as judged by the smallness of their testicles, are lavishly transformed: their fully nude bodies are coated in gold and silver dust, and their erections, maintained by a leather binding, are painted red from tip to base. Hoisted into the air to perform on the swings of the 'Rainbow Show', the dazzling gilt men fly through the air with the greatest of ease, and their bodies sparkle in the 'five colours' reflecting off the mirror ball (Nagano 1974a, p. 55).

The kaleidoscopic spectacle may simply be read as a curious conclusion in which the setting of the circus logically sees its entertainers colourfully painted; the reference to minstrelsy is simply a red herring. Yet, in the Japanese genealogy of the black cultural presence, racial masquerade is a recurring trope. Sometimes, it is set with reference to a specifically black audio culture of alterity whose historical lineage is traced back to minstrel entertainment. In Yamada's novella, for example, music - the domain most associated with black sensuality and physicality (Russell 2006) - seduces Kim into performing a grotesque blackface:

Tina Turner was on the radio. I thought about those amazing thick lips of hers, and seeing my reflection in the dressing table mirror, I took out my red lipstick, outlined my lips with a brush to make them look twice as large as normal, and carefully filled them in.

(Yamada 2006, p. 53) 
Confronted by Spoon, or rather the black authenticity that he represents, the drag show is exposed for its ludicrousness. In this critical moment, Kim's attempts to narrate Spoon's blackness throughout the novel are reversed: 'It made me realize how little I knew about him, and I began to panic' (58). Far from ensuring her own empowerment through the owning of his beguiling racial powers - sensuality, sexuality, simplicity - her access to them is irreversibly closed and she is rendered impotent, nothing other than Japanese: 'Then he looked up and began to laugh out loud. The look in his eyes told me he knew everything there was to know about me' (59).

For the protagonist of Shiiku, racial transformation takes the form of the grotesque body, a putrid disfigurement and moral abjection that comes as a result of the stereotypical flipside to mysterious swinging and low sweet black rhythms: 'the Negro was [... ] singing in a deep, rich voice, singing a strangely vivid song that fascinated us, a song in which both grief and triumph crouched ready to spring on us at any moment' (Ōe 1981, p. 44). The flipside was black violence: "It stinks," he said. "The hand you got smashed stinks awful, doesn't it." I gazed back into Harelip's eyes. [... ] "It's not me that smells. It's the smell of the nigger"' (Ōe 1981, p. 58). In Ōe's story, racial drag is replaced by a far more profound 'internalisation of the foreign male body'. The ambivalent oscillation between desire for and disgust at the black man results in the boy protagonist's loss of innocence, an allegory of the irreversible encounter with modernity (Molasky 1999, pp. 76, 82).

And then there is Kurahara Koreyoshi's very warped 1964 Kuroi Taiyo (Black Sun). This 'anti-buddy picture', as film critic Chuck Stephens describes it, pairs Kawachi Tamio - bad-boy regular in Japan's cinematic nouvelle vague ${ }^{10}$ - as Mei, and the enigmatic Chico Roland as Gil, who regularly lent this nouvelle vague (not to mention ads for Nachiguro-brand kuro ame, or molasses sweets) an interracial exoticism that through his brief appearances complicated 1960s Japanese post-war composure and America's cultural presence therein. ${ }^{11}$

This story of a young Japanese petty criminal obsessed with jazz whose fate becomes entangled with that of a black American soldier on the run from the military police is in turns a cross-cultural black comedy of manners, a Japanese-black homosocial romance, an ode to jazz and a perverse polemic on American antiblack racism. It hauls out all of the images and idioms we've so far encountered, though with the ambiguous edge that characterised the nouvelle vague's vision. There is the visceral bodily presence which is represented as a bestial physicality: sweat, smell, oozing wounds and an often crazed look of pain and bewilderment accented by Godard-esque camera angles and a pounding Max Roach jazz score. There are the themes of blackness as peripheral and blackness associated with captivity: in flight from the authorities, Gil is forced to hide in a derelict church, crawl through gutters and cower in empty industrial chemical barrels, all of whose claustrophobic darkness is highlighted by extreme use of lighting. There 
is also black voicelessness. Gil cannot speak Japanese and instead he grunts in English and screeches or, calling on but also challenging stereotypes of black musical sensuousness, he sings Langston Hughes' 'Six-Bits Blues', if poorly. Finally, while graphic nudity is not on offer, phallic references abound, with images of black men on trumpets punctuating the mise-en-scène, and Gil wielding his machine gun which kills Mei's dog, destroy's Mei's home and, eventually, frees Gil as he makes his escape, literally ascending towards the sun tied to a weather balloon.

However, it is the audacious, slapstick reference to minstrelesque colouring-up to which I wish to draw attention. Here, Gil is forced to paint his face white in order to make his escape with Mei, coloured-up as black. This masquerade is inspired by the album cover for Charles Mingus' The Clown, a title that morally characterises Gil's situation, that sees him reduced to mocking black-American history. At one point early on in the film and in one of the few full lines he utters, Gil reproaches in disgust all those black musicians who kowtow to white patrons: '[T] hose aren't my friends, they are all traitors.' Making their way to Mei's regular haunt, a jazz bar, the customers marvel at their encounter with a real black man. Recalling the memories of white slave-owners of antebellum plantations which we encountered above in 'Jigoku', they force him to dance. Their expectations of seeing a flurry of cool moves are disappointed: ' $[\mathrm{H}] \mathrm{e}$ 's useless, forget him,' says one, to which another quips, 'You wanna sell me this slave?'

The critical, if caricatured, appraisal of American history is clear, even if, in this possibly cynical staging, it risks reinforcing the racism it seeks to challenge. Yet, in common with Yamada's and Ōe's stories, racial play in this scene effects a fundamental moral turn. The balance between a fetishistic longing for an imagined blackness and the disgust felt at an actual encounter is reconfigured into an intimacy borne of empathy that only serves to highlight both Gil's and Mei's shared marginal existence. As Gil inexorably proceeds to his tragic fate, desperate in his increasing weakness and diminishing in his presence, an inner humanity is unlocked in Mei. To be sure, his hitherto frivolous and wayward meanderings through life suggested a latent critique of bourgeois normality which is also represented as an uneasy but powerful Japanese-American collusion. Mei's passion for jazz lent a racialised edge, while the casting of Kawachi brought to this edge an inter-textual association drawing off of the rebel-without-a-cause, bad-boy image for which he became famous in earlier films. In the deepening relationship with Gil, however, Mei comes to articulate a more strident and higher-stakes moral commentary on race, and the placid society more generally. In the final scene, it is Mei who wields the machine gun; he possesses the power - if fleetingly - to hold off the authorities in pursuit and to release Gil to his salvation. ${ }^{12}$ Moving beyond the pastiche of blacking-up, Mei embodies Gil's blackness by holding the phallic power of his gun on the one hand, and on the other he is rendered impotent in his now complete abjection from society. 


\section{The carnivalesque and communitas of colouring-up}

If, in Yamada's, Ōe's and Kurahara's work, racial drag and racial transformation are the mechanisms through which the protagonists' cultural identities are reconfigured and morally transformed, in 'Jigoku' it is in a kind of racial transferral that the status of the Japanese slaves is re-inscribed. Here, sado-masochism is structured in mise en abime-, porn within porn-fashion: at one level, there is the narrative spectacle of sexualised and sexual performance of the Gold and Silver Gilt Show; this is fixed into the wider generic textual spectacle that is the pornographic tale itself. The libidinously liminal fantasy is doubled up so that the veritable carnival of the Gold and Silver Gilt Show is also the carnivalesque of sado-masochistic excess. In this story's plenitude of the liminal condition, it becomes possible to imagine a 'temporary liberation from the prevailing truth and from the established order [... ] a true feast of time, the feast of becoming, change, and renewal' (Bakhtin 1984, p. 10). Indeed, the Gold and Silver Gilt Show is an initiation in which the transition from novice to accomplishment is represented in the form of racial mimesis. The various ordeals suffered by the Japanese slaves detail a process of bodily metamorphisis that, when the finale is considered, lends the power of authenticity from the original - the black master to the copy - the enslaved Japanese protagonist who '[gets] hold of something by means of its likeness' (Taussig 1993, p. 21). In this case, he gets a hold of the black man's 'thing', and in the technicolored interstices of the Rainbow Show, his erection is made to stand out prominently in red, a colour of sexual potency and virility. His body disciplined in the crucible of the training 'Hell', the Japanese protagonist emerges anew through the act of colouring-up, not into black, but a more brilliant version of his own race, to draw on phenotypical codes, from yellow through silver into gold.

The racial-mimetic act of colouring-up can also be seen to establish 'a palpable, sensuous connection between the very body of the perceiver and the perceived' (Taussig 1993, p. 21). While this definition may include the sex acts that follow the Rainbow Show, we might also consider a rainbow alliance of race or, as Victor Turner (1969, p. 138) might observe, 'spontaneous communitas', a relationship that appears in 'liminal situations - phases betwixt and between states where social-structural role-playing is dominant [...] to stand outside the totality of structural positions one normally occupies in a social system [...] to be in ecstasy'. Turner is here largely describing traditional and/or spiritual ritual transitions - though also mundane modern ones, too - but it also aptly describes the 'magical' moment that is visualised in the Rainbow Show. In this rite de passage that sees the Japanese elevated, literally, a complex image of racial reciprocity, or at least colour co-ordinating, is drawn: to the Japanese performer's painted-red erection, the black ring master is wrapped in a red fundoshi, a Japanese loincloth whose bulging prominence, on the one hand, may be redolent of Japanese virility and masculinity, but whose colour, in deviating from the more usual white, 
complicates a straightforward mimicry and, hence, appropriation of pure Japanese masculinity.

There is also a kind of levelling, not so much in the direct character relationships: indeed, the black masters are never seen to relinquish their superordinate position in the racial hierarchy; the black sexual menace is maintained. Rather, this levelling concerns how the text itself inter-textually negotiates history. Its appeals to black sexual stereotype, its encoding of black menace through a reversed trope of slavery and its racial play as evoked through cultural memories by proxy of minstrelsy and colouring-up draw up not simply a pornography of homo sado-masochism, but a pornographics of sex/race to quirky effect. Never mind, as earlier argued, that the black menace intervened in the white-to-Japanese parity to disabuse the Japanese of their privileged junior position in the post-war settlement, a position upon which dominant Japanese narratives of the transition from wartime into post-war are premised. These dominant narratives are wholly destabilised, since this pornographics of sex/race admits the fantastic scenario of a world without whites, ${ }^{13}$ a carnivalesque gesture that 'parodies [the] sacred texts': that is, a history which understands defeat, occupation and, later, Japan's integration into America's Pacific Order as a positive whitewashing (Mackintosh 2010, pp. 94-134).

\section{A world without whites}

In introducing into this discussion Turner's 'spiritual communitas', a concept that shares much affinity with Bakhtin's 'carnival' - a 'temporary liberation from the prevailing truth and from the established order' (Bakhtin 1994, p. 199) - I do not propose that 'Jigoku' made any pretense to being a Fanon-esque revolutionary document, either propagating the revolutionary ideologies of the Third-World movement that saw, for instance, Asian Americans and blacks align on the other side of the Pacific (Omatsu 2000), or advocating pre-war theories of mixed-race empire as an antidote to white supremacism (Oguma 2002, pp. 285-288, Dower 1999 , p. 208). Which is not to say that the emergence of a politicised black presence into the public sphere in America, and popular culture internationally, was wholly uninfluential. Indeed, as I have discussed elsewhere, Japan's first magazines for the men who love men should not be understood, in their early years at least, as a venue circumscribed only to the exploration of homo-sexuality (Mackintosh 2010). Very occasionally, race intervened to interrogate norms of Japanese manliness and male-male desire. ${ }^{14}$ Regular contributor to Barazoku and Adon Nōkami Teruki (1972, p. 21), for example, excoriated the attempts of an 'ugly white-pig of a middle-aged foreigner' to seduce a very masculine Japanese mountaineer. Offensively racist, it nonetheless spoke to a variety of concerns in which desire, race, manliness and nation intersected in troubling ways: a denunciation of the white male 'rice queen' who fetishises a normally younger Oriental male; the gendering of Japan and Japanese men as 'feminine' to 
America's white 'masculine' principle; and the post-war post-colonial settlement which saw a decolonised Japan incorporated into America's neo-colonial order. Note here that the incident to which Nōkami refers took place in 1964, and that two decades earlier the hysterical foreigner and/or his compatriots might well have been one of the troops subjugating an occupied Japan. Meanwhile, the disillusionment expressed by Barazoku editor Fujita Ryū (1971, p. 56) at the racial segregation of New York's gay scene is palpable, yet his coupling with a 'Jamaica Joe' nevertheless seems to have been matched by an emergent visibility in popular culture: stills of actor Bernard Greene from scenes in William Friedkin's 1970 film Boys in the Band (The Boys in the band 1972, pp. 57, 59); and one of actor Cleavon Little's Super Soul in Richard Sarafian's Vanishing Point (Inai 1974, p. 57). Admittedly, these three, which form three-fifths of the images I found in my sampling of magazines dedicated to the exploration and/or consumption of male-male desire from 1952 to $1975^{15}$, are statistically insignificant, especially when one considers that white men appeared over ten times as much in the 1950s underground homo magazine Adonisu no kai alone; the same is true of pulp erotica magazines, the so-called füzoku zasshi ('customs magazines') of the $1950 \mathrm{~s}$ and 1960s.

If politics and popular culture are useful to understanding the story that 'Jigoku' tells of a world without whites, or at least a Japanese-to-black nexus of sexual desire, so too is the idea of stereotype, which Bhabha (2004, p. 95) defines as a 'major discursive strategy [...] a form of knowledge and identification that vacillates between what is always "in place", already known, and something that must be anxiously repeated'. In pointing to the 'essential duplicity of the Asiatic or the bestial license of the African', Bhabha does not seek to evaluate their veracity or even a counter-discursive deployment of them. Rather he is interested in the 'process of ambivalence' that makes this mode of representation contradictory, 'as anxious as it is assertive' (Bhabha 2004, p. 100). Anxious, because the identities that stereotype seems to fix are ever so slippery. In 'Jigoku', the genealogies of blackness - animal sexuality as signified by penis-to-body-to-race and slavery - may be essential to the black menace, but in the context of Japan's historical defeat, this menace stirs anxiety over America's Japanese subjugation, and blackness becomes truly menacing.

It is also assertive, since this pornographics of sex/race is, by convention, a stylisation of excess, its representations so totalised, so utterly fantastic as to expose the tallness of the tale; ambivalence transmogrifies into ambiguity to render the libidinal liminal, and the minstrel-esque performance of colouring-up - an excessively pornographic vision of flying red penises within a pornographic text of sado-masochistic excess - is a point of momentary confusion when black and yellow blur. 'Jigoku' is hardly an auteur's meditation on the radical potential of minstrelsy, such as was suggested in Kurahara or even Yamada, but insofar as the act of colouring-up implicates an exchange of sorts between the subject and his Other, it lends itself to confounding stereotype even as it might maintain it. This 
much is valid in the undeniably differing cultural explorations of Ōe to Kurahara to Yamada, and back again to 'Jigoku'. This ambiguity is what helps explain why minstrelsy, in its original form but even in its contemporary performance, can be so potent, in particular to imagining an underclass alliance, as Lhamon observes in his history of minstrelsy (Lhamon 1998, p. 152. See also Garrett 2002, pp. 34-36).

If, indeed, the 'rainbow show' in 'Jigoku' is to be understood in the spirit of a rainbow alliance that finds mutual empathy in the historical position and cultural memory of black and Japanese, it is chimeric at best. 'Jigoku' makes no commitment to exploring its implications. Nevertheless, it is crucial to note that Japan's nation-state project was polychromatic from its outset. Although it is often little recalled that Commodore Perry's projection of American soft power included the Olin Japanese Minstrels, apparently to great Japanese acclaim (Yellin 1996), the genealogy of the black presence to which it contributed stirred the imagination in powerful ways so that within Japan's imaginary of itself, there is 'prosthetic' potential for 'the promiscuous mingling of bodies and desires that altogether confuses the racial and social common sense' (Sommerville 2000, p. 440).

\section{Conclusion}

Addressing the mass market of cultural commodities, of which porn is one form, Adorno (1991, p. 99) asserts that 'The entire practice of the culture industry [... ] transfers the profit motive naked onto cultural forms', and within the economic relationship that governs this transfer, 'the masses are an object of calculation, an appendage of the machinery. The customer is not king, as the culture industry would have us believe, not its subject but its object'; the culture industries and the chimera of need and fulfillment they instill are 'their master's voice'. Naked forms, appendages, calculated objectification, machinery, king and master - an undertone of sado-masochistic imagery, not to mention a Hegelian irony that naughtily reverses the roles of master and slave, is evident in Adorno's characterisation of the culture industries. But, to the extent that this story was one of many which saw in Japan's first homo magazines the mass production, distribution and commodification of homo-male sexual fantasy, he is partly right. Forget the moody erotic meditations found in Tanizaki-esque tattoos and Mishimalian tough boys romping in the snow, the new homo media borne of mass-production technology the photocopier - and a profit motive were instrumental in pornifying homo-male sexual fantasy: these magazines that traded in self-gratification, could be read 'd'une seule main' (Screech 2009, p. 40), all for 450 yen each month.

Yet, the generic uniformity that we identified above in the medical and cockand-ball-torture sado-masochistic sub-genres is explained by another factor that should not be ignored. Even as pornification can be understood as mass-market 
commodification, so too is it generated by an aspiration to foment rentaikan, a 'sense of solidarity', amongst men who love men, which defined the historical moment of the early 1970s that saw the emergence of Japan's first homo magazines (Mackintosh 2010). As a reader contribution, and one that sparked other readers' reactions, the scenarios described in 'Jigoku' - crudely narrated and formulaic as they may have been - were a form of potent dialogic sentiment, an expression of one's own fantasy to declare one's own presence, to seek empathy and possibly to move others in the new-found knowledge that many share this same desire, homo and sado-masochistic alike: 'I read the inaugural issue of Adon', writes the author of 'Jigoku', 'and I just wanted to write something, so I decided to write a little bit whenever I had time and send something [in]. [Readers], please contact me through the magazine. I wish your magazine every success' (Nagano 1974a, p. 50).

In 'Jigoku' and many productions like it, commodification and community are the flipsides of a burgeoning collective project to spark association, virtual and actual. Starting with the lone ad in the inaugural issue of $S a b u^{16}$ for the Athena-Ueno shop ([advert] 1974, p. 154), for example, which sold 'Homo, SM (photos, $8 \mathrm{~mm}$ [film], books), SM equipment, rubber, leather . . .', the homo sadomasochistic commerce-cum-community grew so that just over five years on Sabu's offshoot Aitsu, more hardcore, visual and glossy, included review introductions of SM clubs like Romanesque in Osaka's northern homo quarter (Osaka romanesuku 1980, pp. 60-61). Featuring a photo of Shiro, its master (owner and dominant sado-masochistic position), whose boyish face and diminutive frame belie an authoritative presence, we learn that the Imperial Japanese army uniform he wears and soldier's sword he waves are not simply props selling a business personae. Nor are they simply artifacts recalling his past life as a lieutenant during the war. Insofar as the uniform recalls within him 'hatred in abundance' at the violations he suffered - tied up, raped and forced to fellate his military superior, all the while 'flowing tears burning with shame' - this uniform bridges history. Within these detestable memories is 'a paradox', a strange urge which led him years after the war finally to purchase second-hand the uniform he is seen wearing in the photo. In donning it for the first time, he 'embraced a feeling like longing', whose meaning and effect were profoundly sexual. Memories were not only relived, but they are seen to script the present as a contradiction, made sense of through his sado-masochistic interests and enterprise. In the pages of Sabu and Aitsu and as seen in Shiro's interview confessional, then, the reader is escorted from fiction to fact, life imitating art.

The story of Romanesque's master is instructive, not so much because it asks us to believe that the author of 'Jigoku' is in some way truthful and to be taken as plausible. Not at all, since realism isn't here the measure of meaning. Rather, Shiro demonstrates why history matters. It can pique memories by calling to the fore emotional and psychological trauma, and in the concatenation of bodily affects that Shiro's uniform is said to have awakened - anguish, indignity, arousal and 
ecstasy - history-in-the-present created through memories-resurrecting-the-past are seen to invest one with all the power of a master or, shifting our attentions to the protagonist of 'Jigoku', all the impotence of a slave. Which is why the story of Master Shiro in his Imperial army uniform, and why the libidinously liminal fantasy of 'Jigoku' are culturally potent. ' $\mathrm{S} / \mathrm{M}$ is haunted by memory,' argues McClintock in her apologia for this sexual form:

By reinventing the memory of trauma and staging loss of control in what is really a situation of excessive control, the player gains symbolic power over perilous memory. $\mathrm{S} / \mathrm{M}$ affords a delirious triumph over memory and, from this triumph, an orgasmic excess of pleasure.

(2003, pp. 642-643)

In 'Jigoku', perilous memory recalls foreign subjugation. Its 'paraphernalia of $\mathrm{S} / \mathrm{M}$ ' - probing medical instruments, chains, testicular restraints, urethral electrical prongs and even the colouring-up dust of silver and gold - is not simply the disciplining 'paraphernalia of state power', but the 'outrageous staging' of the neo-colonial subjugation of the Japanese nation (McClintock 2003, pp. 642-643).

Note McClintock's deployment of the language of drama to plot her analysis: 'staging', 'player', 'paraphernalia': ' $\mathrm{S} / \mathrm{M}$ is a theatre of transformation,' she writes. 'S/M performs the "primitive irrational" as a dramatic script; a theatrical, communal performance' (McClintock 2003, pp. 641). Halperin (1995, p. 89), inspired similarly by Foucault, takes us further, identifying it as a 'theatrical display of masculinity', but not as a 'revalorisation of the male as male'. To the contrary, the hypermasculine contest of male-on-male genital torture is experienced in this community of players - including by proxy in the reading of 'Jigoku' as a 'devirilisation under the sign of masculinity, thereby forging a new association between masculinity and sexual receptivity or penetrability, while detaching male homosexuality from its phobic association with "femininity" (Halperin 1995, pp. 89-90). In this reading, ' $\mathrm{S} / \mathrm{M}$ finds other erotic uses for the genitals than that of stimulation to the point of orgasm [...] a re-mapping of the body's erotic sites [...] even a re-eroticisation of the male genitals as sites of vulnerability instead of as objects of veneration' (Halperin 1995, p. 88). 'Desexualisation' is what Halperin calls this, and herein is found the ultimate irony of the male-male, cockand-ball torture tale of 'Jigoku'. In this 'outrageous staging' (McClintock 2003, pp. 641) of Japan's mid-twentieth-century violation, the perilous memory that 'prosthetically' conjures the black presence to highlight a white absence, not only converts 'public punishment' into 'private desire' (McClintock 2003, pp. 642-3). Rather, it skirts an axiomatic heteronormativity that can only conceive of the foundational narrative of post-war Japan in the terms of 'feminisation': in the 'highly sexualised' gendered transaction of the occupation, writes Igarashi (2000, p. 29) 'the drama casts the United States as a male and Hirohito and Japan as a docile female, who unconditionally accepts the United States' desire for self-assurance'. 
By the mid-1970s, following a decade of spectacular economic growth, some in Japan were no longer in thrall to the might of America, nor its men; this much was seen in Nōkami's racist invective and Fujita's racial disappointment. While the occupation could not be denied, especially when America enforced Japan's junior position in its Pacific order, history could still be re-narrated with a twist. In its libidinously liminal imagination that saw Japanese men subjected to the black menace, the sado-masochistic fantasy of 'Jigoku' re-eroticised the site of the genitals, and fancifully, the protagonist is elevated into a position of power, if temporarily, that was in keeping with the bizarre scenario of this tale.

But, there is more, since the black menace in 'Jigoku' is, after all, a fairy-story fabrication drawn from a genealogy of the black presence in Japan, a manipulation of racial stereotypes that confirms the centrality of the Japanese subject, who is also the Japanese reader. The warning given by McClintock (2003, p. 641) is here apropos: 'To argue that in $S / M$ "whoever is the 'master' has power and whoever is the 'slave' has not", is to read theatre for reality.' Which is all to say that race and sex do not simply play on culture; they can stylise its most audaciously excessive desires in a sex/race pornographics of cock and balls that should not be dismissed simply as a load of cock and bull.

\section{Notes}

1. The early-to-mid 1970s are notable in the history of homosexuality for the emergence of the homo magazine, Japan's first commercially marketed and nationally distributed publications catering to male homosexuals, starting with Barazoku in 1971. This monthly men's lifestyle magazine brought together highbrow essays, entertainment reviews, discussion forums, fashion guides, personal ads and pornographic art and fiction, much of which was reader-created. Common to all of the homo magazines was a concern to promote a sense of solidarity amongst homo. Unique to Adon, however, were efforts to import into Japan the politics of gay liberation then burgeoning in the Anglo-American west. Although its editor Minami Teishirō would go on to become a leading gay activist in Japan, Adon, like the other homo magazines until their demise at the close of the twentieth century, would come to be dominated largely by pornography and the promotion of Japan's male-male sex industry (Mackintosh 2010, pp. 5, 16, 22-23).

2. Victor Turner (1969, p. 95) defines 'liminality' as 'ambiguous and indeterminate', as 'neither here nor there; they are betwixt and between the positions assigned by law, custom, convention, and ceremonial'. McClintock, in her analysis of sado-masochistic fantasy and practice, calls it the 'enchantment of [its] magic circle', to highlight a ludic potency which 'reverses and transmutes social meanings' that can be all the more dangerous because it is temporary (McClintock 1993, p. 208).

3. By 'genre', I refer not only to stylistic and narrative conventions, but to a consumption practice determined largely by the capitalist opportunities of the sexual economy (Wicke 1993, pp. 68-69).

4. The reference to medicalised understandings of race in 'Jigoku' may not only have drawn from an imagination of the American subjugation of Japan. Here, we might cite Endō Shūsaku's 1958 novel The Sea and Poison, whose images of human vivisection on American pilots form a critical appraisal of the Imperial Japanese army's medical experimentation on their prisoners of war, an appraisal that is turned on its head in 'Jigoku'.

5. 'Non-white members of the occupation forces seldom appear in [the] canonical scenes of post-war life' (Molasky 1999, p. 71). With specific reference to certain imaginations in the 
world of post-war homo desire, the Japanese-American relationship is not simply hierarchically configured, but the power differential is imagined in highly affective and sometimes enthusiastic ways, for example, in the ethico-moral, fictive-kin terms of 'father' and 'son' (Mackintosh 2010, pp. 117-131). For contrasting historical and cultural appraisals of the occupation period see, for example, Igarashi (2000), Dower (1999) and Iokibe (1992).

6. 'The reality of Americans in occupied Japan - a reality that the Japanese were quick to identify as discriminatory - was the policy of racial segregation between white and nonwhite soldiers' (Koshiro 1999, pp. 55-56).

7. 'Seldom does the discourse, particularly of its popular enunciations, acknowledge that the presence of black people, various forms of black culture - either directly or indirectly by proxy and their representation in Japan is not confined to the immediate pre-war and post-war periods... [Japanese] exposure to western discourse about blacks [...] in many ways shaped how they would perceive blacks when they actually encountered them' (Russell 2006).

8. In Japanese, the loan-word 'lynch' refers to a severe beating and reveals a knowledge of racial segregation and the mob execution of blacks in the United States from the pre-war period (Dower 1986, p. 208).

9. 'If pornography can be defined simply as a string of sexual numbers hung onto a plot existing primarily as an excuse of sex, then [... ] pornography's closest genre affiliation is the musical in which the lyrical choreography of song and dance numbers resemble the rhythms of the musical' (Williams 2008, p. 266).

10. In addition to his films with Kurahara including the 1960 Kyonetsu no kisetsu, he appeared in Suzuki Seijun's 1965 Shunpuden and Tokyo nagaremono (1966).

11. Roland's filmography reads as a catalogue of Japanese auteur arthouse: Kurahara's 1960 Kyōnetsu no kisetsu, Furukawa Takumi's Aoi machi no ōkami 1962, Suzuki Seijun's 1964 Nikutai no mon and Kō Nakahira's Yarō ni kokkyō wa nai.

12. In this most bizarre closing scene, Gil escapes on a weather balloon that is secured by a tether, which Mei severs with a volley of bullets. The ending is ambiguous: his trussed-up body hangs upside down to suggest a lynching at the hands of white American soldiers.

13. Of course, such a fantasy, ironically, is possible because whiteness in historical reality cannot be disregarded in these kinds of inter-racial imaginations.

14. In addition to Mackintosh (2010), see Suganuma (2012), Reichert (2006) and Pflugfelder (2000).

15. The other two include an image of an American soldier approaching a female Japanese prostitute (Amanuma 1954, p. 37) and a shot of a nude man in Adonisu no kai (Mokuji [table of contents] 1954, p. 2).

16. A homo magazine specializing in male-male sado-masochism.

\section{References}

Adorno, T., 1991. The culture industry. London: Routledge.

Amanuma W., 1954. Kegasareta Nihon no teisō. Füzoku kagaku, October, 37-43.

Aoi machi no ōkami, 1962. Film. Directed by Furukawa Takumi. Japan: Nikkatsu.

Athena-Ueno [advert], 1974. Sabu, 1 (November), 154.

Avery, T., 1938. The isle of Pingo Pongo. USA: Warner Bros.

Bakhtin, M., 1984. Rabelais and his world. Translated by H. Iswolsky. Bloomington: Indiana University Press.

Baskett, M., 2009. The attractive empire: transnational film culture in imperial fapan. Honolulu: University of Hawai'i Press.

Bhabha, H.K., 2004. The Location of culture. London: Routledge Classics.

The boys in the band, 1972. Barazoku, 3 (January), 56-61. 
Dower, J.W., 1986. War without mercy: race and power in the Pacific War. New York: Pantheon.

Dower, J.W., 1999. Embracing defeat: Fapan in the wake of World War II. New York: Routledge.

Dvorak, G., 2008. 'The Martial Islands': making Marshallese masculinities between American and Japanese militarism. The Contemporary Pacific, 20 (1), 55-86.

Endo, S., 1972. The Sea and poison. Translated by M. Gallagher. London: Peter Owen.

Foucault, M., 1990. The use of pleasure: the history of sexuality, vol. 2. Translated by. R. Hurley. New York: Vintage Books.

Fujita R., 1971. Natsu no tabi de atta seinentachi. Barazoku, 2 (November), 52-57.

Garrett, S.M., 2002. Return of the repressed. Theatre, 32 (2), 26-43.

Hall, S., 1980. Encoding/decoding. In: S. Hall, D. Hobson, A. Lowe, and P. Willis, eds. Culture, media, language. London: Hutchinson, 117-127.

Halperin, D.M., 1995. Saint Foucault: towards a gay hagiography. New York: Oxford University Press.

Highmore, B., 2002. Everyday life and cultural theory: an introduction. Abingdon, UK: Routledge.

Igarashi, Y., 2000. Bodies of memory: narratives of war in postwar fapanese culture, 1945-1970. Princeton, NJ: Princeton University Press.

Inai, H., 1974. Eiga o mite homo wa kodoku da nante uso da to omou koto. Adon, 1 (May), 56-59.

Iokibe, M., 1992. Japan meets the United States for the second time. In: C. Gluck and S.R. Graubard, eds. Showa: the Japan of Hirohito. New York and London: W.W. Norton, 91-106.

Kelly, M.G.E., 2010. International biopolitics: Foucault, globalisation and imperialism. Theoria, 57 (123), 1-26.

Kelsky, K., 2001. Women on the verge: Fapanese women, western dreams. Durham: Duke University Press.

Knowles, M., 2002. Tap dancing: the early history of tap dancing. Jefferson, NC: McFarland.

Koshiro, Y., 1999. Trans-Pacific racisms and the US occupation of Japan. New York: Columbia University Press.

Kuroi taiyō, 1964. Film. Directed by Kurahara Koreyoshi. Japan: Nikkatsu.

Landsberg, A., 1995. Prosthetic memory: Total Recall and Blade Runner. Body and Society, 1 (3-4), $175-189$.

Lhamon, W.T. Jr, 1998. Raising Cain: blackface performance from fim Crow to hip hop. Cambridge, Ma: Harvard University Press.

Low, M., 2003. The emperor's sons go to war: competing masculinities in modern Japan. In: K. Louie and M. Low, eds. Asian masculinities: the meaning and practice of manhood in China and Japan. London: RoutledgeCurzon, 81-99.

Mackintosh, J.D., 2010. Homosexuality and manliness in postwar fapan. Abingdon, UK: Routledge.

Male genitorture, 2010. LondonFetishScene. Available from: http://www.londonfetishscene.com/ wipi/index.php/CBT [Accessed 27 November 2011].

McClintock, A., 1993. Maid to order: commercial s/m and gender power. In: P.C. Gibson and R. Gibson, eds. Dirty looks: women, pornography, power. London: British Film Institute, 207-231.

McClintock, A., 2003. Imperial leather: race, cross-dressing and the cult of domesticity. In: R. Lewis and S. Mills, eds. Feminist postcolonial theory: a reader. Edinburgh: Edinburgh University Press, 635-666.

Mokuji [table of contents], 1954. Adonisu no kai. 15 (April), 2.

Molasky, M.S., 1999. The American occupation of Japan and Okinawa: literature and memory. London: Routledge.

Mui, C.L., 1991. Review of Hard core: power, pleasure, and the 'frenzy of the visible' by Linda Williams and For adult users only: the dilemma of violent pornography. NWSA fournal, 3 (1), $117-121$.

Nagano H., 1974a. Jigoku ni ochita wakamonotachi. Adon, 3 (August), 50-55.

Nagano H., 1974b. Jigoku ni ochita wakamonotachi [cont.]. Adon, 4 (September), 42-45. 
Nikutai no mon, 1964. Film. Directed by Suzuki Seijun. Japan: Nikkatsu.

Nōkami, T., 1972. Essei romanchika. Barazoku, 5 (May), 20-25.

Ōe, K., 1959. Shiiku. In: Shisha no ogori, Shiiku. Tokyo: Shinchō bunko, 79-141.

Ōe, K., 1981. The catch. In: The catch and other war stories. Translated by J. Bestor. Tokyo: Kodansha International, 15-61.

Oguma, E., 2002. A genealogy of 'Fapanese' self-images. Tranlated by D. Askew. Melbourne: Trans Pacific Press.

Omatsu, G., 2000. The 'Four Prisons' and the movements of liberation: Asian American activism from the 1960s to the 1990s. In: M. Zhou and J.V. Gatewood, eds. Contemporary Asian America: a multidisciplinary reader. New York: New York University Press, 80-112.

Osaka romanesuku, 1980. Aitsu, Summer, 60-61.

Pflugfelder, G., 2000. Cartographies of desire: male-male sexuality in fapanese discourse, 1600-1950. Berkeley: University of California Press.

Reichert, J., 2006. In the company of men: representations of male-male sexuality in Meiji literature. Stanford: Stanford University Press.

Russell, J.G., 1991. Race and reflexivity: the black other in contemporary Japanese mass culture. Cultural Anthropology, 6 (1), 3-25.

Russell, J.G., 2006. Authenticating alterity: stereotypes of the black other in Japan and the United States. Cool Fapan Lecture [podcast], 20 September 2006, MIT Cambridge, Massachusetts. Anime-Pulse.com. Available from: http://www.anime-pulse.com/wp-content/uploads/2007/04/ cooljapan09202006-johnrussell.pdf [Accessed 27 November 2011].

Screech, T., 2009. Sex and the floating world: erotic images in fapan 1700-1820. 2nd ed. London: Reaktion Books.

Shumpuden, 1965. Film. Directed by Suzuki Seijun. Japan: Nikkatsu.

Sommerville, S.B., 2000. Queering the color line: race and the invention of homosexuality in American culture. Durham, NC: Duke University Press.

Suganuma, K., 2012. Contact moments: the politics of intercultural desire in fapanese male-queer cultures. Hong Kong: Hong Kong University Press.

Taussig, M., 1993. Mimesis and alterity: a particular history of the senses. New York: Routledge.

Tempest, 2006. The Toybag guide to medical play. Oakland: Greenery Press.

Tokyo nagaremono, 1966. Film. Directed by Suzuki Seijun. Japan: Nikkatsu.

Turner, V., 1969. The ritual process: structure and anti-structure. Ithaca, NY: Cornell University Press. Wicke, J., 1993. Through a gaze darkly: pornography's academic market. In: P.C. Gibson and R. Gibson, eds. Dirty looks: women, pornography, power. London: British Film Institute, 62-80.

Williams, L., 2008. Screening sex. Durham, NC: Duke University Press.

Yamada, A., 2006. Bedtime eyes. In: Bedtime Eyes. Translated by Y. Gunji and M. Jardine. New York: St. Martin's Press, 3-64.

Yamada, E., 1987. Beddotaimuaizu. Tokyo: Kawade bunko.

Yarō ni kokkyō wa nai, 1965. Nikkatsu. Directed by Nakahira Kō. Japan: Nikkatsu.

Yellin, V.F., 1996. Mrs. Belmont, Matthew Perry, and the 'Japanese Minstrels'. American Music, 14 (3), 257-275.

Jonathan D. Mackintosh is Lecturer in World History at the University of Plymouth, U.K. His research interests include gender/sexuality in postwar Japan, masculinities and the body, and historical East Asian diasporic identities. He published Homosexuality and Manliness in Postwar Japan (Routledge, 2010) and Cultural Studies and Cultural Industries in Northeast Asia (University of Hong Kong Press, 2009), a collected volume coedited with C. Berry and N. Liscutin. He may be contacted at: jonathan.mackintosh@plymouth.ac.uk. 